\title{
PREVALENCE OF URINARY TRACT INFECTION AND ANTIMICROBIAL SUSCEPTIBILITY AMONG DIABETIC PATIENTS
}

\author{
DANA CARMEN ZAHA, CLAUDIA MARIA JURCA *, LUCIA GEORGETA DAINA, COSMIN \\ MIHAI VESA, AMORIN REMUS POPA, ALEXANDRU DANIEL JURCA, MARIANA \\ MURESAN, OTILIA MICLE
}

University of Oradea, Faculty of Medicine and Pharmacy, $1^{\text {st }}$ December Street, 410073, Oradea, Romania

*corresponding author: claudiajurca70@yahoo.com

Manuscript received: May 2019

\begin{abstract}
The aim of this study was to characterize the prevalence of urinary tract infections (UTIs) in patients with diabetes mellitus, antimicrobial susceptibility pattern of the isolates and to explore the relationship with glycaemic balance. 1046 patients with diabetes, 84 with type 1 and 962 with type 2 diabetes were enrolled in the study. Each urine sample obtained by midstream collection was evaluated using dipstick and microscopical evaluation of the sediment, followed by uroculture. Most patients were diagnosed with type 2 diabetes, and the incidence of UTIs was $29.82 \%$. The predominant isolates were E. coli and $K$. pneumoniae, followed by E. faecalis. The first two isolates were susceptible to cephalosporins, aminoglycosides, carbapenems, combinations with clavulanic acid or sulbactam, less to quinolones and resistant to ampicillin. Isolates strains of $E$. faecalis have shown a good sensitivity to antibiotics. No difference was noted between the samples with $E$. coli, $K$. pneumoniae and E. faecalis in terms of glycaemic balance.
\end{abstract}

\section{Rezumat}

Scopul acestui studiu a fost de a evalua prevalența infecțiilor tractului urinar la pacienți cu diabet zaharat, susceptibilitatea antimicrobiană a tulpinilor izolate și de a explora relaţia cu echilibrul glicemic. Au fost luați în studiu 1046 de pacienți cu diabet zaharat, 84 cu tip 1 și 962 cu tip 2. Fiecare probă de urină obținută prin recoltarea jetului mijlociu a fost evaluată biochimic precum și microscopia sedimentului, urmată de urocultură. Majoritatea pacienților au fost diagnosticați cu diabet zaharat de tip 2, iar prevalența infecției urinare a fost de $29,82 \%$. Tulpinile izolate predominant au fost $E$. coli și $K$. pneumoniae, urmate de E. faecalis. Primele două au fost susceptibile la cefalosporine, aminoglicozide, carbapeneme, combinații cu acid clavulanic sau sulbactam, mai puțin la chinolone și rezistente la ampicilină. Tulpinile de E. faecalis au demonstrat o bună sensibilitate la antibiotice. Nu s-a observat nici o diferență între infecțiile urinare cu $E$. coli, $K$. pneumoniae și E. faecalis în ceea ce privește echilibrul glicemic evaluat prin valorile hemoglobinei glicozilate.

Keywords: bacteriuria; diabetes mellitus; aetiology, antimicrobials

\section{Introduction}

Diabetes mellitus (DM) has become a serious public health threat because of its complications and mortality. The association between diabetes mellitus and an increased susceptibility to infection is well-known; immunity is altered in patients with diabetes due to depressed function of polymorphonuclear leukocytes, particularly when acidosis is also present, leukocytes adherence, chemotaxis, and phagocytosis [3, 23]. The imbalance in the antioxidant systems involved in bactericidal activity is also described $[1,15]$. In addition, other conditions such as bladder dysfunction (incomplete bladder emptying) caused by diabetic neuropathy also may contribute to the increased risk for urinary infections. Evidence suggest that urinary tract infection (UTI) is the most common bacterial infection among diabetic patients [7, 9, 24]. Several studies have demonstrated a higher incidence of bacteriuria in diabetic patients, more in diabetic women than in nondiabetic women $[6,14]$. Metabolic comorbidities or unhealthy lifestyle may result in poor glycaemic control and complications [11, 21, 22]. There is evidence that improving glycaemic control in patients improves immune function and prevents the appearance and progression of complications $[10$, $18,21]$. Recently, the use of SGLT2 inhibitors has produced concern about an increased risk of urinary tract infections in recipients of these medications because the levels of urinary glucose increased with greater doses of the medication.

The extent of involvement ranges from inconsequential lower urinary tract colonization (asymptomatic bacteriuria) to acute cystitis, complicated lower UTI (including catheter associated UTI), pyelonephritis and complicated pyelonephritis/urosepsis.

The present study was undertaken to assess the prevalence of UTIs, antimicrobial susceptibility pattern of bacterial isolates and the relationship with glycaemic 
balance among adult diabetic patients attending the Oradea County Emergency Clinical Hospital, Romania.

\section{Materials and Methods}

We performed a hospital-based study conducted for two years (between January 2017 and December 2018) at the Oradea County Emergency Clinical Hospital, Romania. Socio-demographic characteristics, associated factors and clinical and laboratory data were extracted from the hospital computer system and medical records of patients admitted the diabetic clinic resulting in a number of 1046 of patients presenting urinary symptoms (dysuria, suprapubic pain and/or fever at presentation). A "mid-stream" urine sample obtained under aseptic precautions in sterile containers before starting treatment with antibiotics. Specimens were transported in sterile containers and analysed within maximum two hours from their collection. Urine specimens were analysed by dipstick and microscopy, and then cultured using a calibrated loop. The standard definition of a UTI on culture is more than 100,000 colony forming units per $\mathrm{mL}(\mathrm{CFU} / \mathrm{mL})$. The identification of isolates was performed using Maldi Tof and antibiotic sensitivity by Vitek-2 Compact Systems and Kirby-Bauer disk diffusion method. The isolate was classified as susceptible, intermediate, or resistant based on the Clinical Laboratory Standards Institute (CLSI) criteria [5]. E. coli ATCC 25922, S. aureus ATCC 29213, $P$. aeruginosa ATCC 27853, E. faecalis ATCC 29212 were used as quality control strains to check the quality of culture media, and antimicrobial cards and disks.

\section{Results and Discussion}

The results show that among the urine samples collected from patients, 403 exhibited bacterial and yeast growth (38.52\%) and 643 samples $(61.47 \%)$ did not showed any bacterial growth. A number of 91 samples were excluded from the study because they showed mixed growth of bacteria or were considered colonization susceptible due to an improper collection of the sample.

The 312 patients included were classified according to the glycaemic status as can be seen in the Table I. They were between 21 and 91 years of age and the mean age was 66 years $( \pm 12.45)$. A large proportion of the patients $(68.95 \%)$ was found to be in the age group between 61 and 80 years. The ratio women to men is 2.62 . Females with diabetes type 2 had a higher prevalence of urinary tract infection than men like the one noted by Renko et al. [21]. About $91.02 \%$ of type 2 and $8.97 \%$ of type 1 diabetic patients had UTIs. The HbA1c of patients with and without UTI were $9.11 \%( \pm 2.92)$ and $7.13 \%( \pm 1.3)$ respectively. 60 patients $(19.23 \%)$ with UTI were having HbA1c $<7$ and 252 patients $(80.76 \%)$ with UTI were having $\mathrm{HbAlc} \geq 7$.

The same patients with positive cultures had higher glycosylated haemoglobin values (more than 8.5) and more frequently complications (ketoacidosis, macrovascular or/and microvascular complications). The most common complications were cardiac and chronic obliterative arterial disease, cerebrovascular, nephropathy and neuropathy. In multivariate analysis, comparing the risk factors for the presence of urinary tract infections diagnosis in the initial group of 1046 patients with positive or negative bacterial growth, the presence of stroke in the medical history was statistically significant positively associated with UTI and male sex was statistically significant negatively associated with UTI. Therefore, diabetic patients with stroke history, especially females, are highly susceptible to UTIs. In univariate analysis the association between positive medical history for stroke and UTI persisted ( $p<0.0001)$, meaning that this macro complication of diabetes mellitus is an independent predictor of UTI presence.

Table I

Characteristics of patients according the value of $\mathrm{HbAlc}$

\begin{tabular}{|c|c|c|c|c|c|}
\hline \multirow{2}{*}{\multicolumn{2}{|c|}{ Parameters }} & \multirow{2}{*}{ No } & \multicolumn{2}{|c|}{ HbA1c (\%) } & \multirow[b]{2}{*}{$\mathbf{p}$} \\
\hline & & & $<7(n=60)$ & $\geq 7(n=252)$ & \\
\hline \multirow{2}{*}{ Gender } & Male & 86 & 11 & 75 & \multirow[b]{2}{*}{0.07} \\
\hline & Female & 226 & 49 & 177 & \\
\hline \multirow{7}{*}{ Age } & $21-30$ & 2 & 0 & 2 & \multirow[b]{7}{*}{0.35} \\
\hline & $31-40$ & 4 & 0 & 4 & \\
\hline & $41-50$ & 21 & 3 & 18 & \\
\hline & $51-60$ & 61 & 6 & 55 & \\
\hline & $61-70$ & 106 & 18 & 88 & \\
\hline & $71-80$ & 105 & 28 & 77 & \\
\hline & $81-90$ & 13 & 5 & 8 & \\
\hline \multirow{2}{*}{$\begin{array}{l}\text { Type of } \\
\text { diabetes }\end{array}$} & Type 1 & 28 & 8 & 20 & \multirow[b]{2}{*}{0.18} \\
\hline & Type 2 & 284 & 52 & 232 & \\
\hline \multirow{3}{*}{$\begin{array}{l}\text { Complications } \\
\text { of diabetes }\end{array}$} & Ketoacidosis & 24 & 1 & 23 & \multirow[b]{3}{*}{0.55} \\
\hline & $\begin{array}{l}\text { Microvascular complications (retinopathy, nephropathy, } \\
\text { neuropathy) }\end{array}$ & 242 & 11 & 231 & \\
\hline & $\begin{array}{l}\text { Macrovascular complications (ischemic cardiopathy, chronic } \\
\text { obliterative arterial disease, cerebrovascular disease) }\end{array}$ & 268 & 23 & 197 & \\
\hline
\end{tabular}


The overall isolation rate of uropathogens in this study was $29.82 \%$ which is higher than other reports. Many studies have reported an increased prevalence of asymptomatic bacteriuria in diabetic patients ranging from $8 \%-26 \%$. This difference could be due to the difference in geographic area, samples size and processing techniques. As expected, the prevalence and the distribution of Gram-negative and Grampositive bacteria isolated from the clinical sample's different levels of glycaemia expressed as HbA1c is clearly higher in the less controlled glycaemic group (Table II).

Among our isolates, Gram-negative aerobic rods accounted for $84.61 \%$ while Gram-positive cocci accounted for the remaining $15.38 \%$ of the total pathogens. E. coli (55.22\%), Klebsiella pneumoniae (19.28\%) and Enterococcus faecalis (7.37\%) were found to be more prevalent among our patients. The same distribution of etiological agents has reported by other studies $[2,4,8,17]$. On the other hand, more than $83 \%$ of isolates were Enterobacterales and the most of urinary tract infections were due to Gramnegative bacteria (265 isolates; $86.60 \%$ ) contrary to the study conducted by Manikandan et al. were Staphylococcus aureus was responsible for $20.5 \%$ of UTI cases $[13,16]$.

Table II

Values of HbA1c and the pathogens isolated from urine specimens

\begin{tabular}{|l|c|c|c|}
\hline \multirow{2}{*}{} & \multicolumn{2}{|c|}{ HbA1c(\%) } & \multirow{2}{*}{ Total no. (\%) } \\
\cline { 2 - 3 } & Gram-negative bacilli \\
\hline E. coli & 43 & 126 & $169(54.16)$ \\
\hline Klebsiella spp. & 5 & 54 & $59(18.91)$ \\
\hline Enterobacter (cloacae, aerogenes) & 2 & 10 & $12(3.84)$ \\
\hline Proteus spp. & 1 & 9 & $10(3.20)$ \\
\hline P. aeruginosa & 1 & 5 & $6(1.92)$ \\
\hline Acinetobacter baumannii & 1 & 3 & $4(1.28)$ \\
\hline Morganella morganii & 0 & 2 & $2(0.64)$ \\
\hline Citrobacter spp(cloacae, freundii) & 0 & 2 & $2(0.64)$ \\
\hline & Gram-positive cocci & \\
\hline Enterococcus faecalis & 5 & 20 & $25(8.01)$ \\
\hline Streptococcus (mitis, agalactiae) & 0 & 11 & $11(3.52)$ \\
\hline Enterococcus faecium & 0 & 4 & $4(1.28)$ \\
\hline S. aureus & 0 & 2 & $2(0.64)$ \\
\hline Candida spp & 2 & 4 & $6(1.92)$ \\
\hline
\end{tabular}

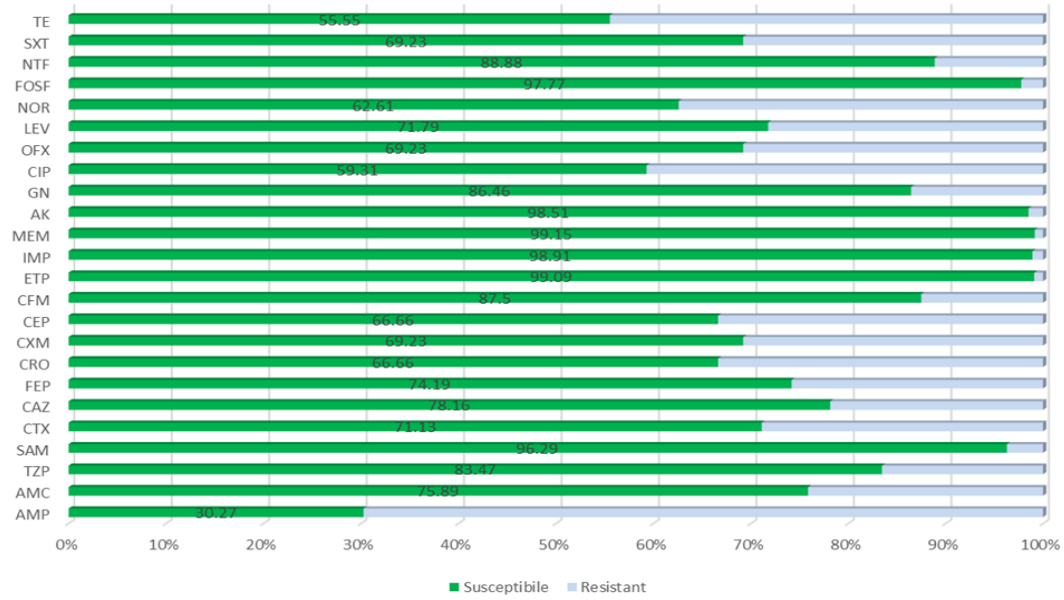

Figure 1.

The susceptibility of E. coli

AMP - Ampicillin, AMC - Amoxicillin/clavulanic acid, TZP - Piperacillin/Tazobactam, SAM - Ampicillin/Sulbactam, CTX - Cefotaxime, CAZ - Ceftazidime, FEP - Cefepime, CRO - Ceftriaxone, CXM - Cefuroxime, ETP - Ertapenem, IMP - Imipenem, MEM - Meropenem, AK - Amikacin, CN - Gentamicin CIP-Ciprofloxacin, LEV-Levofloxacin, NOR-Norfloxacin, FOS-Fosfomycin, NTF-Nitrofurantoin, SXT-Trimethoprim / Sulfamethoxazole

Type 2 diabetes is also a risk factor for fungal UTI, mostly caused by Candida species and the majority are clinically asymptomatic. In our study group, Candida species were present in $6(1.92 \%)$ of the positive cultures and 4 strains in patients with HbA1c $>8.5 \%$. Although a small number of Acinetobacter baumannii 
FARMACIA, 2020, Vol. 68, 2

and Pseudomonas aeruginosa strains have been identified, they are significant because of their increase resistance to antibiotics [25].

E. coli strains isolates exhibited a good sensitivity to the antibiotics, except for ampicillin $(30.27 \%)$ and ciprofloxacin $(59.31 \%)$. They were more susceptible to norfloxacin $(62.61 \%)$, ofloxacin $(69.23 \%)$, levofloxacin $(71.79 \%)$ and nitrofurantoin $(88.88 \%)$. The sensitivity to aminoglycosides was also good, being $98.51 \%$ for amikacin and $86.46 \%$ for gentamycin. The susceptibility of $E$. coli strains to cephalosporins was the best for ceftazidime $(78.16 \%)$, cefixime $(87.5 \%)$, cefepime (74.19\%) and less for cefuroxime $(69.23 \%)$, and ceftriaxone $(66.66 \%)$ as can be seen in the Figure 1. Similarly, a lower prevalence of antimicrobial resistance to cephalosporins and quinolones and a higher haemoglobin A1c level was described in diabetic patients with E. coli urosepsis [24]. Extended-spectrum beta-lactamases Escherichia coli isolates were identified in $18.40 \%$, a single strain producing carbapenems and $27.16 \%$ had resistance to quinolones when it tested at least two.

In the current study, Klebsiella pneumonia showed resistance against commonly used antibiotics: cephalosporins, combinations (amoxicillin/clavulanic acid, piperacillin/tazobactam), quinolones and gentamycin, but were susceptible to fosfomycin, carbapenems, amikacin (Figure 2). Although reports shown higher carbapenem resistance in Romania, in the present study the susceptibility rate for the tested $K$. pneumoniae was $75.67-79.54 \%$ lower than in E. coli. Unfortunately, a number of 18 strains were producing extendedspectrum beta-lactamases $K$. pneumoniae, and 4 were carbapenemase producing.

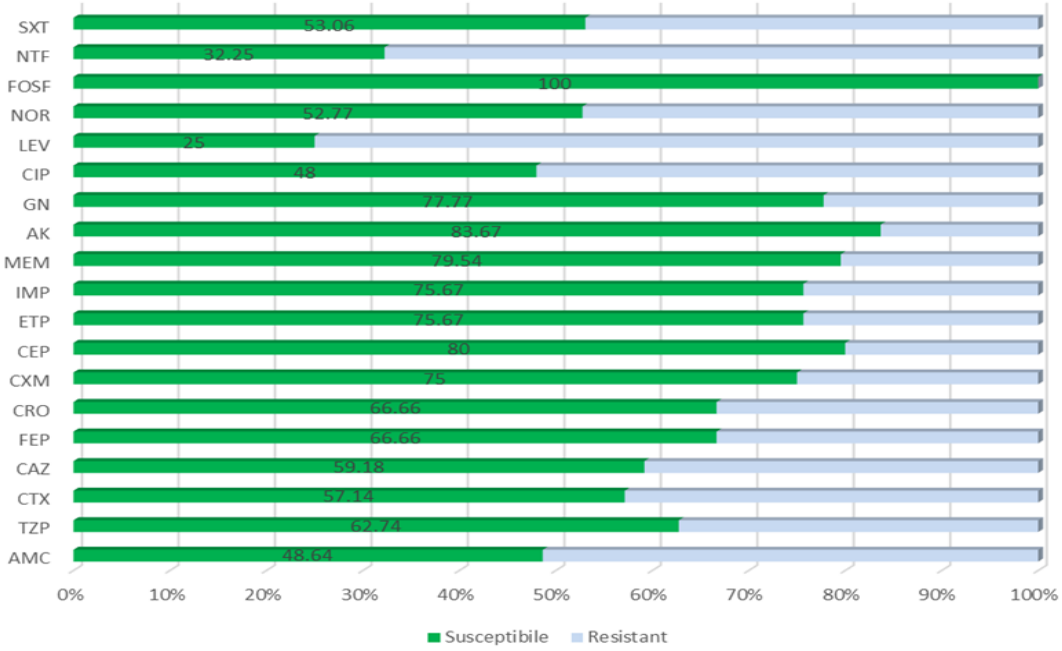

Figure 2.

The susceptibility of Klebsiella pneumoniae

AMP - Ampicillin, AMC - Amoxicillin/clavulanic acid, TZP - Piperacillin/Tazobactam, SAM - Ampicillin/Sulbactam, CTX - Cefotaxime, CAZ - Ceftazidime, FEP - Cefepime, CRO - Ceftriaxone, CXM - Cefuroxime, ETP - Ertapenem, IMP - Imipenem, MEM - Meropenem, AK - Amikacin, CN - Gentamicin CIP-Ciprofloxacin, LEV-Levofloxacin, NOR-Norfloxacin, FOS-Fosfomycin, NTF-Nitrofurantoin, SXT-Trimethoprim / Sulfamethoxazole

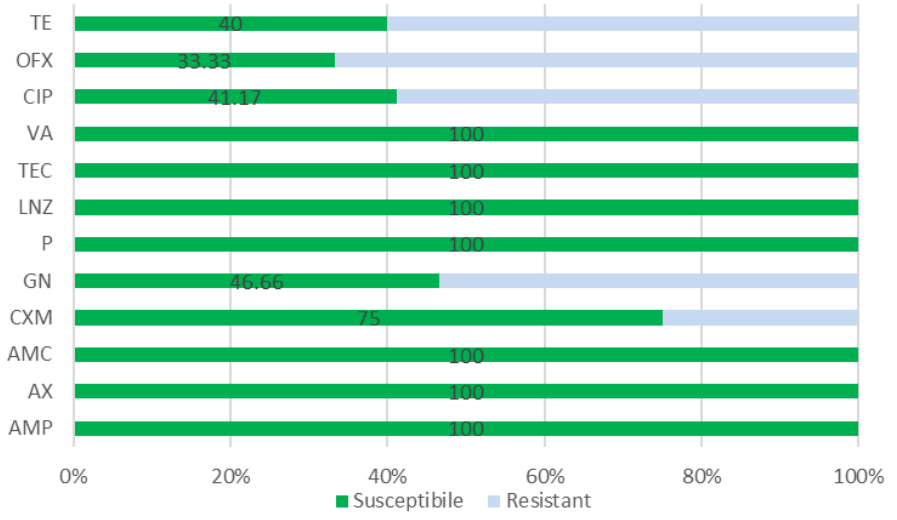

Figure 3.

The susceptibility of Enterococcus faecalis strains

AMP - Ampicillin, AX-Amoxicillin, AMC - Amoxicillin/clavulanic acid, CXM - Cefuroxime, CN - Gentamycin, P - Penicillin, ERY - Erythromycin, LNZ - Linezolid, TEC - Teicoplanin, VA - Vancomycin, CIP - Ciprofloxacin, OFX - Ofloxacin, MXF - Moxifloxacin, TE - Tetracycline 
The third etiological agent for the patients included in our study was Enterococcus faecalis (7.37\%). These isolates showed a higher level of sensitivity to ampicillin, amoxicillin, amoxicillin-clavulanic acid, cefuroxime, penicillin, linezolid, teicoplanin, and resistant to gentamycin, quinolones, tetracycline. No strain of E. faecalis showed vancomycin resistance. In a study from India amongst the Gram-positive isolates, Enterococcus faecalis was the most commonly isolated organism with $3.2 \%$ resistance to vancomycin [16].

\section{Conclusions}

The successful treatment of UTI in diabetic patients depends on the proper identification of the bacteria responsible and the selection of effective antimicrobial agents against them. More important is the increase in resistance to some antimicrobial agents. Appropriate antibiotic therapy with effective diabetic management is special in diabetic patients with bacteriuria because of the higher incidence of complications and involvement of upper urinary tract. Resistance to antimicrobial agents is growing and represents a challenge in the treatment of infectious diseases today. In addition to the rational use of antibiotics, natural compounds might offer favourable alternatives based on their antioxidant and disinfectant properties solutions can also be considered auxiliary medical therapies $[12,19]$. This study is important for clinicians in order to facilitate the empiric treatment of patients and management of patients with symptoms of UTIs and help those responsible to formulate antibiotic prescription policies.

\section{Conflict of interest}

The authors declare no conflict of interest.

\section{References}

1. Asmat U, Abad K, Ismail K, Diabetes mellitus and oxidative stress - A concise review. Saudi Pharm J., 2016; 24(5): 547-553.

2. Aswani Srinivas M, Chandrashekar UK, Shivashankara KN, Pruthvi BC, Clinical profile of urinary tract infections in diabetics and non-diabetics, Australasian Med J., 2014; 7(1): 29-34.

3. Casqueiro J, Casqueiro J, Alves C, Infections in patients with diabetes mellitus: A review of pathogenesis. Indian J Endocrinol Metab., 2012; 16(Suppl1): S27-S36.

4. Chiță T, Licker M, Sima A, Vlad A, Timar B, Sabo $\mathrm{P}$, Timar R, Prevalence of urinary tract infections in diabetic patients. Rom J Diabetes Nutr Metab Dis., 2013; 20: 99-105.

5. Clinical and Laboratory Standards Institute (CLSI) (2018). Performance Standards for Antimicrobial Disk Susceptibility Tests.

6. Frydrych LM, Fattahi F, He K, Ward PA, Delano MJ, Diabetes and sepsis: Risk, recurrence and ruination. Front Endocrinol., 2017; 8: 1-22.
7. Fünfstück R, Nicolle LE, Hanefeld M, Naber KG, Urinary tract infection in patients with diabetes mellitus. Clin Nephrol., 2012; 77(1): 40-48.

8. Golli AL, Nițu FM, Bălăşoiu M, Rascu S, Lungu MA, Dinescu SN, Ciobanu Mitrache L, Glodeanu A, Văcaru M, Olteanu M, Microbiological profile and antibiotic resistance pattern of bacterial uropathogens among hospitalized patients. Farmacia, 2019; 67(1): 167-173.

9. Hirji I, Guo Z, Andersson SW, Hammar N, GomezCaminero A, Incidence of urinary tract infection among patients with type 2 diabetes in the UK General Practice Research Database (GPRD). J Diabetes Complications, 2012; 26(6): 513-516.

10. Hoza A, Moldovan C, Fărcaș DM, Pallag A, Nemeth S, Marc F, Comparative study of oral antidiabetic therapy and insulin therapy on hepatic steatosis in patients with type 2 diabetes mellitus. Farmacia, 2018; 66(4): 652-657.

11. Jurca C, Bembea M, Pallag A, Mureșan M, Szilagyi A, Balmoș A, Pop O, Jurca A, Dobjanschi L, Pharmacotherapeutical considerations in the treatment and management of neonatal hyperammonaemia. Farmacia, 2018; 66(2): 216-222.

12. Jurca T, Baldea I, Filip GA, Olteanu D, Clichici S, Pallag A, Vicas L, Marian E, Micle O, Muresan M, The effect of Tropaeolum majus L. on bacterial infections and in vitro efficacy on apoptosis and DNA lesions in hyperosmotic stress. $J$ Physiol Pharmacol, 2018; 69(3): 1-11.

13. Kebamo S, Dabso R, Deressa A, Gebrie M, Urinary tract infection: bacterial etiologies, drug resistance profile and associated risk factors among diabetic patients attending Nekemte Referral Hospital, Ethiopia. Am J Curr Microbiol., 2017; 5(1): 19-31.

14. Lecube A, Pachón G, Petriz J, Hernández C, Simó R, Phagocytic activity is impaired in type 2 diabetes mellitus and increases after metabolic improvement. PLoS One, 2011;6(8): 1-6.

15. Maiese K, New insights for oxidative stress and diabetes mellitus. Oxidative Medicine and Cellular Longevity. 2015; 2015: 1-17.

16. Mandal J, Acharya NS, Buddhapriya D, Parija SC, Antibiotic resistance pattern among common bacterial uropathogens with a special reference to ciprofloxacin resistant Escherichia coli. Indian J Med Res., 2012; 136(5): 842-849.

17. Manikandan S, Ganesapandian S, Singh M, Kumaraguru AK, Emerging of multidrog resistance human pathogens from urinary tract infections. Curr Res Bacteriol., 2011; 4(1): 9-15.

18. Nitzan O, Elias M, Chazan B, Saliba W, Urinary tract infections in patients with type 2 diabetes mellitus: review of prevalence, diagnosis, and management. Diabetes Metab Syndr Obes., 2015; 8: 129-136.

19. Pallag A, Filip GA, Olteanu D, Clichici S, Baldea I, Jurca T, Micle O, Vicaş L, Marian E, Soriţău O, Cenariu M, Mureşan M, Equisetum arvense L. extract induces antibacterial activity and modulates oxidative stress, inflammation, and apoptosis in endothelial vascular cells exposed to hyperosmotic stress. Oxid Med Cell Longev., 2018; 2018: 1-14.

20. Popa AR, Vesa CM, Uivarosan D, Jurca CM, Isvoranu G, Socea B, Stanescu AMA, Iancu MA, Scarneciu I, 
FARMACIA, 2020, Vol. 68, 2

Zaha DC, Cross sectional study regarding the association between sweetened beverages intake, fast-food products, body mass index, fasting blood glucose and blood pressure in the young adults from North-western Romania. Rev Chim., 2019; 70(1): 156-160.

21. Renko M, Tapanainen P, Tossavainen P, Pokka T, Uhari M, Meta-analysis of the significance of asymptomatic bacteriuria in diabetes. Diabetes Care, 2011; 34(1): 230-235.

22. Schneeberger C, Kazemier BM, Geerlings SE, Asymptomatic bacteriuria and urinary tract infections in special patient groups: women with diabetes mellitus and pregnant women. Curr Opin Infect Dis., 2014; 27(1): 108-114.
23. Szablewski L, Sulima A, The structural and functional changes of blood cells and molecular components in diabetes mellitus. Biol Chem., 2017; 398(4): 411-423.

24. Wang MC, Tseng $\mathrm{CC}, \mathrm{Wu} \mathrm{AB}$, Lin $\mathrm{WH}$, Teng $\mathrm{CH}$, Yan JJ, Wu JJ, Bacterial characteristics and glycemic control in diabetic patients with Escherichia coli urinary tract infection. J Microbiol Immunol Infect., 2013; 46(1): 24-29.

25. Zaha DC, Bungau S, Aleya S, Tit DM, Vesa CM, Popa AR, Pantis C, Maghiar OA, Bratu OG, Furau C, Moleriu RD, Petre I, Aleya L, What antibiotics for what pathogens? The sensitivity spectrum of isolated strains in an intensive care unit. Sci Total Environ., 2019; 687: 118-127. 